\title{
GLUCAGON ANTIBODIES AND AN IMMUNOASSAY FOR GLUCAGON *
}

\author{
By ROGER H. UNGER, ANNA M. EISENTRAUT, M. S. MCCALL ANd LEONARD L. \\ MADISON WITH THE TECHNICAL ASSISTANCE OF KATHRYN R. SIMS, \\ LUCILLE TIMM AND LORETTA PATMAN \\ (From the Department of Medicine and Radioisotope Laboratory, Veterans Hospital; and \\ the Department of Medicine, University of Texas Southwestern Medical School, \\ Dallas, Texas)
}

(Submitted for publication February 6, 1961 ; accepted March 30, 1961)

Despite extensive knowledge of the amino acid composition of beef-pork glucagon, and of the physiologic changes induced by its administration to animals and man, the role of glucagon in the homeostatic regulation of blood glucose level in normal and abnormal states remains to be defined. This fundamental gap in knowledge is the result of the lack of a method sufficiently specific and sensitive to measure endogenous glucagon in body fluids.

Previous efforts to assay glucagon in plasma have been based upon ability to produce either hyperglycemia in a living animal (1-3), glycogenolysis in liver slices (4), or phosphorylase activation in liver homogenates (5). There is reason to doubt the specificity of the plasma glucagon-like activity detectable by such methods (6), and their status is at present in question.

The greater specificity inherent in immunoassays (7), coupled with the unprecedented sensitivity provided by the paper radiochromato-electrophoretic techniques of Berson and co-workers (8) suggested that a radio-immunoassay for glucagon might provide a hitherto unequaled range of specific measurements. In a preliminary report, the antigenicity of beef-pork glucagon in rabbits was recorded and the feasibility of a radioimmunoassay for glucagon demonstrated (9). The development by Berson and Yalow of a radio-immunoassay for insulin of remarkable sensitivity and specificity $(10,11)$ has validated this approach to problems of peptide hormone assay.

In the following report the antigenicity of glucagon is demonstrated, glucagon antibodies are

* Supported by United States Public Health Service Grant A-2700. Portions of this study were presented at the Central Society for Clinical Research, Chicago, I11., November 6, 1959, and the American Society for Clinical Investigation, Atlantic City, N. J., May 2, 1960. characterized in respect to their specificity and the kinetics of their reaction with glucagon, and a radio-immunoassay for glucagon capable of measuring as little as 50 -millionths of a microgram of glucagon is described.

METHODS AND MATERIALS

\section{Antibody studies}

A. Immunization. Forty-seven white female rabbits, each weighing more than 5 pounds, were employed in this study. Twenty-nine were given monthly injections of Lilly beef-pork glucagon ${ }^{1}$ in the complete Freund's adjuvant for 3 months and at irregular and less frequent intervals thereafter; 18 control animals received similarly scheduled injections of either Lilly beef-pork "glucagon-free" insulin in complete Freund's adjuvant (7 rabbits) or complete Freund's adjuvant alone (5 rabbits), and 6 rabbits were given no injections at all.

Premixed Lilly beef-pork glucagon solution was added with sterile technique to an equal volume of the complete Freund's adjuvant and mixed at room temperature on an automatic paint shaker. At least 15 minutes was required for emulsification; $2 \mathrm{ml}$ of emulsion containing $1 \mathrm{mg}$ of glucagon was administered to each rabbit; $0.2 \mathrm{ml}$ was injected in a footpad and the remainder subcutaneously in a hindquarter.

B. Radioiodination of glucagon. The procedure employed is a modification of the Pressman-Eisen technique (12) and is being reported elsewhere in greater detail (13). To $50 \mathrm{mc}$ of $\mathrm{NaI}^{131}$, chilled in a beaker of ice, 3 drops of $0.1 \mathrm{NaNO}_{2}$ are added; $2.5 \mathrm{~N} \mathrm{HCl}$ is added dropwise, to give a $\mathrm{pH}$ of about 2.0 . Then $0.05 \mathrm{ml}$ of 0.001 $\mathrm{N}$ KI and 1 drop of $\mathrm{NaNO}_{2}$ are added; $50 \mu \mathrm{g}(0.1 \mathrm{ml})$ of chilled glucagon is rapidly added. Prompt addition of 2 to $3 \mathrm{ml}$ of glycine buffer with thorough but gentle mixing follows, and the $\mathrm{pH}$ is raised to 9.0 or above. The material is then dialyzed for 3 hours in $250 \mathrm{ml}$ of chilled glycine buffer containing $15 \mathrm{ml}$ of washed resin (Amberlite 401). The buffer is maintained in an ice bath and the resin gently agitated by a magnetic stirrer. The dialyzed material is transferred to a tube containing

\footnotetext{
${ }^{1}$ Kindly supplied by Dr. W. R. Kirtley, Eli Lilly, Inc., Indianapolis, Ind.
} 
enough albumin to provide a final albumin concentration of 5 per cent. This solution is passed through a Resikit to reduce further the nonprotein-bound radioactivity. The final glucagon- $\mathrm{I}^{131}$ solution is frozen immediately and stored until needed.

The technique described provides a high specific activity without undue damage to the glucagon molecule. Biologic assays of one lot of glucagon- $\mathrm{I}^{131}$, kindly performed by Dr. W. Bromer of Eli Lilly, Inc., failed to demonstrate loss of biologic activity despite many weeks of storage. In general, an atom: molecule ratio of $0.7: 1$ can be anticipated.

C. Detection of antibodies. Serum obtained from each rabbit prior to the monthly injection was studied by the Berson, Yalow and Volk technique adapted for glucagon$I^{131}$ (14). This method is based upon the observation that glucagon- $\mathrm{I}^{131}$, when incubated in normal serum and then applied to a filter-paper strip, is adsorbed to the paper at the point of its application (origin) and will not, under these circumstances, migrate either chromatographically or electrophoretically, thereby permitting its separation from the serum proteins. In the presence of glucagon antibodies, however, glucagon- $\mathrm{I}^{131}$ might be expected to bind to and migrate with globulin in a mannner similar to that described for insulin- $\mathrm{I}^{131}$ and insulin antibodies (8).

One $\mathrm{ml}$ of undiluted serum was incubated on a rotating shaker at $37^{\circ} \mathrm{C}$ for 1 to 3 hours with $10 \mathrm{~m} \mu \mathrm{g}$ of glucagon$\mathrm{I}^{131}$. In the more recent studies this has been followed by overnight incubation at $4^{\circ} \mathrm{C}$. From 20 to $100 \mu 1$ of this mixture was then applied to a Whatman $3 \mathrm{MM}$ filterpaper strip. In a barbital buffer, ionic strength 0.05 , $\mathrm{pH} 8.6$, the strips were subjected to electrophoresis with hydrodynamic flow ${ }^{2}$ in a Spinco model $\mathrm{R}$ electrophoresis cell with a current of 10 ma for 1 hour, followed by electrophoresis alone at $2.5 \mathrm{ma}$ for 16 hours. Strips were heat-dried at $120^{\circ} \mathrm{C}$ for 1 hour and stained with naphthol blue-black dye. The strips were counted in an Actigraph counter with a TGC-2 Geiger-Müller tube. Count-rate tracings were obtained by means of a Rectiriter recorder (Texas Instruments).

In other studies not requiring separation of the individual serum protein fractions, the strips were loaded with up to $300 \mu 1$ and subjected to horizontal chromatography for periods up to 2.5 hours, during which time the proteins migrate at least 2 inches from the origin. After drying and staining, the strips were cut so as to separate completely the origin from the protein area. Each half of the strip was counted in a well-type scintillation counter. All samples were counted until a total of at least 10,000 counts was obtained. Berson, Yalow, and Volk have shown that a small fraction of glucagon$\mathrm{I}^{131}$ damaged by irradiation or other factors, during or after the iodination procedure, migrates nonspecifically with serum proteins (14). Parallel control runs em-

\footnotetext{
${ }^{2}$ Hydrodynamic flow occurs if the slit at the top of the cell cover is left open. The resulting evaporation provides the necessary flow to move $\gamma$-globulin away from the origin.
}

ploying undiluted serum from unimmunized rabbits were, therefore, carried out with every run in order to distinguish between nonspecific protein-binding of damaged glucagon- $\mathrm{I}^{131}$ and specific antibody-binding of undamaged glucagon $-\mathrm{I}^{131}$. The damaged moiety ranged from 4.8 to 20 per cent of the glucagon- $\mathrm{I}^{131}$ lots employed in this group of studies, but was almost always less than 10 per cent.

In addition to the Berson-Yalow techniques, the SkomTalmage technique (15), originally introduced for the study of nonprecipitating insulin antibodies, was adapted without change except that glucagon- ${ }^{131}$, glucagon-challenged rabbit serum, and sheep antirabbit globulin serum were substituted for insulin- $\mathrm{I}^{\mathbf{1 3 1}}$, human anti-insulin serum, and antihuman globulin serum, respectively.

\section{Immunoassay for glucagon}

A. Principles of the radio-immunoassay. The reaction between radioantigen and antibody can be quantitatively expressed as a ratio of the migrating or antibody-bound glucagon- $\mathrm{I}^{131}$ to the nonmigrating or free glucagon- $\mathrm{I}^{131}$. This ratio will be referred to henceforth as the $B / F$ ratio. It was shown previously that, if the amount of glucagon- $\mathrm{I}^{131}$ and antibody in the system is kept constant, the introduction of progressively increasing amounts of nonradioactive glucagon, by competing with glucagon- $\mathrm{I}^{131}$ for antibody, will cause a progressive decrease in the $B / F$ ratio of glucagon $-I^{131}(9)$. As in the Yalow-Berson (11) and Grodsky-Forsham (16) insulin assays, it is the relationship between the quantity of unlabeled antigen introduced and the $B / F$ ratio of the radioantigen which forms the basis of the immunoassay.

B. Materials. Antiserum. All rabbit sera capable of binding 50 per cent or more of $10 \mathrm{~m} \mu \mathrm{g}$ of glucagon- $\mathrm{I}^{131}$ per $\mathrm{ml}$ were pooled, to assure a large stockpile of serum of uniform antibody concentration.

Glucagon standards. Solutions of unlabeled beef-pork glucagon premixed in Lilly glucagon diluent ${ }^{3}$ were made up in 5 per cent human albumin solution in concentrations of from 50 to $10,000 \mu \mu \mathrm{g}$ per $\mathrm{ml}$. These can be stored frozen without notable loss of glucagon.

Glucagon- $I^{131}$. Batches of glucagon- $\mathrm{I}^{131}$ with specific activities ranging from 93 to $234 \mathrm{mc}$ per $\mathrm{mg}$ were prepared as described by the McCall modification (13) of the Pressman-Eisen (12) technique. Five per cent albumin solution was added to the glucagon- $\mathrm{I}^{131}$ to give a stock solution of 1 or $2 \mu \mathrm{g}$ per $\mathrm{ml}$. The albumin prevents adsorption to glassware and minimizes the radiation damage (14) which ranged from 2.06 to 9.60 per cent in the immunoassay studies. Frozen glucagon- $\mathrm{I}^{131}$ can be stored without significant increase in damage for up to 2 weeks. A trace concentration of 50 to 100 $\mu \mu \mathrm{g}$ of glucagon- $\mathrm{I}^{131}$ per $0.1 \mathrm{ml}$ was obtained by diluting 25 to $100 \mu \mathrm{l}$ of stock solution with 2 per cent albumin solution.

${ }^{3}$ Formula of the diluent, kindly supplied by Dr. W. R. Kirtley, is as follows: $981.73 \mathrm{~g}$ of distilled water, $16 \mathrm{~g}$ of glycerin, and $2.27 \mathrm{~g}$ of phenol. The $\mathrm{pH}$ is adjusted to 2.85 with $\mathrm{HCl}$. 


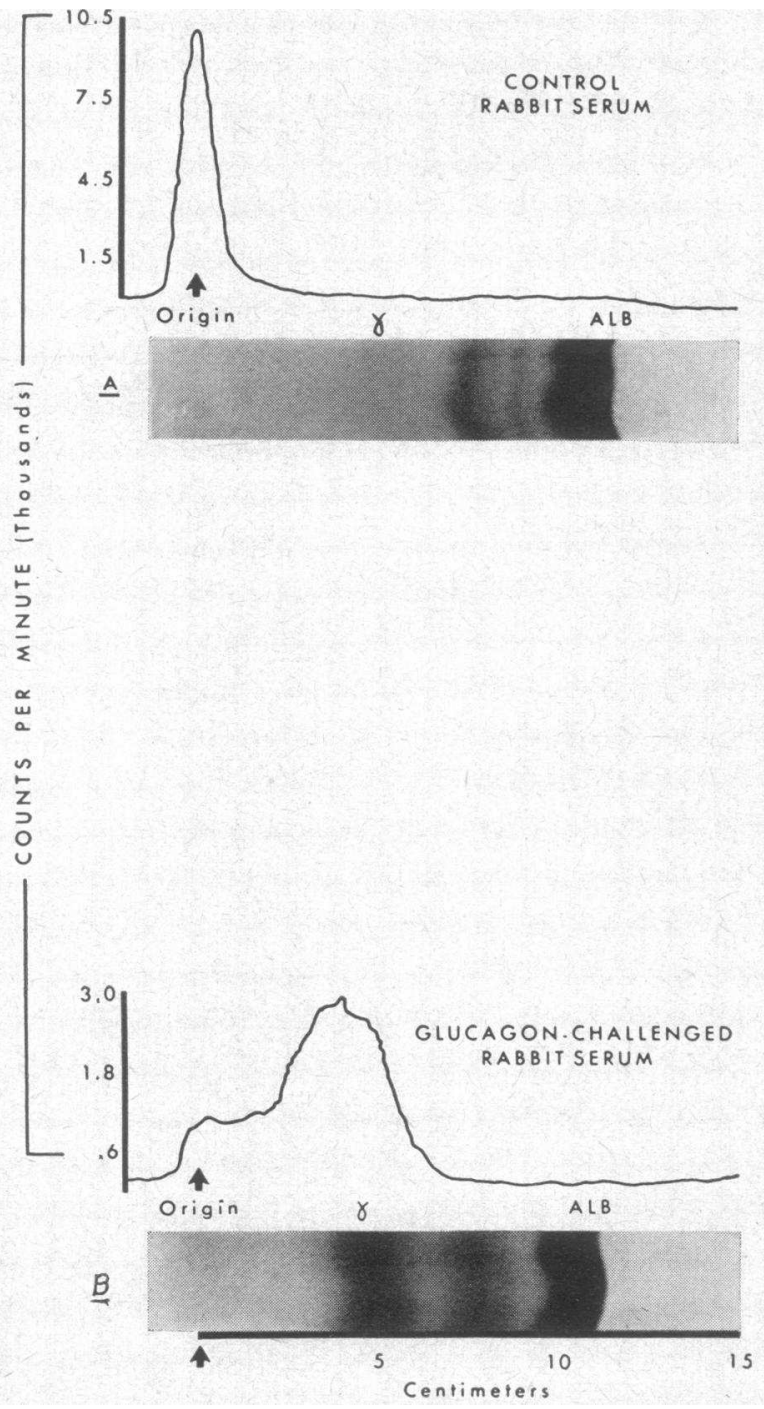

Fig. 1. Control AND gluCAgon-Challenged RABBit SERA. A. When glucagon- $\mathrm{I}^{131}$ is incubated with serum from normal control rabbits, and then subjected to electrophoresis plus hydrodynamic flow, the major fraction of radioactivity remains fixed to the origin of the strip, giving the above pattern of distribution of radioactivity.

B. With serum of rabbits challenged with beef-pork glucagon, the pattern of distribution of radioactivity changes strikingly with a substantial fraction now migrating with the $\gamma$-globulins.

Unknown specimens. In these studies unknown specimens consisted either of heparinized human plasma or crude pancreatic extracts. All blood was centrifuged immediately after collection, and the plasma was separated and promptly frozen until the time of the test. Extracts of pancreatic tissue were made by the method of Sutherland and de Duve (17), and the desiccated residue reconstituted in chloride-phosphate buffer containing 5 per cent albumin.

C. Procedure. 1) One $\mathrm{ml}$ of a 1:100 dilution of pooled high titer rabbit antiserum in physiologic saline was incubated with $1 \mathrm{ml}$ of each glucagon standard (or of an unknown specimen) for 1 hour at $37^{\circ} \mathrm{C}$ in an automatic shaker. 2) One-tenth $\mathrm{ml}$ of glucagon- $\mathrm{I}^{131}$ solution, containing 50 to $100 \mu \mu \mathrm{g}$ of glucagon- $\mathrm{I}^{131}$ was added to each tube in identical quantities and reincubated with shaking for another hour at $37^{\circ} \mathrm{C}$. 3) The mixtures were then incubated at $4^{\circ} \mathrm{C}$ for at least 24 hours. 4) After incubation the mixtures were allowed to reach room temperature, and $0.9 \mathrm{ml}$ of each mixture was loaded on three Whatman $3 \mathrm{MM}$ filter-paper strips, $0.3 \mathrm{ml}$ per strip, arranged in horizontal chromatography cells containing a barbital buffer at $\mathrm{pH} 8.6$, ionic strength 0.05 . 5) These were chromatographed at room temperature for approximately 2.5 hours or until the proteins had migrated to the far end of the strip, their posterior edges at least 2 inches beyond the anterior edge of the origin. A dummy strip containing bromphenol blue dye was used to determine when migration was complete. 6) The strips were heat-dried for 1 hour at $120^{\circ} \mathrm{C}$ and stained with naphthol blue-black dye and air-dried. 7) They were then cut so as to separate clearly the origin from the protein area at the opposite extreme of the strip. The three halves containing the origin and the three halves containing the protein area were carefully folded together and counted in a plastic tube in a $4 \mathrm{cc}$ well-type scintillation counter until a total of at least 10,000 counts was obtained.

Several of the glucagon standards and unknown samples were set up in the identical manner except that serum from non-immune rabbits was substituted for antiglucagon serum. These control strips were necessary to determine the degree of nonspecific protein-bound migration of glucagon- $\mathrm{I}^{131}$ damaged during incubation with the various specimens being assayed, in order to permit calculation of a $\mathrm{B} / \mathrm{F}$ ratio corrected for damage.

$D$. Calculation of $B / F$ ratio corrected for damaged glucagon- $I^{131}$. This was done in the manner described by Yalow and Berson for insulin- $\mathrm{I}^{121}$ (11).

\section{RESULTS}

\section{Antigen-antibody reaction}

Antibody response. When glucagon- $\mathrm{I}^{131}$ was incubated with the serum of normal control rabbits and the mixture applied to a filter-paper strip and subjected to either electrophoresis with hydrodynamic flow or chromatography, all but a small fraction of the radioactivity remained fixed to the origin or point of application, and the pattern illustrated in Figure 1A was obtained.

In the rabbits challenged with monthly injections of beef-pork glucagon in Freund's adjuvant, however, a progressively increasing deviation from 
the above pattern was observed. After the third or fourth injection, a varying but usually substantial portion of the glucagon- $\mathrm{I}^{131}$ migrated with $\gamma$-globulin, giving the radio-electrophoretic pattern typified by Figure 1B.

In Figure 2, glucagon- $\mathrm{I}^{131}$ migration in the sera from the 29 glucagon-challenged rabbits is compared with that of sera from 7 insulin-challenged rabbits, 5 rabbits treated with Freund's adjuvant only, and 6 untreated rabbits. Significant migration of glucagon- $\mathrm{I}^{131}$ with $\gamma$-globulin was encountered only in sera obtained from glucagon-challenged rabbits, averaging 58.5 per cent of $10 \mathrm{~m} \mu \mathrm{g}$ of glucagon- $\mathrm{I}^{131}$ with a range of 13.4 to 84.6 per cent. In serum from the three control groups an average of only 8 per cent of the glucagon- $\mathrm{I}^{131}$ migrated with globulin, with a range of 4.8 to 13.4 per cent. This small percentage of radioactivity which migrated diffusely with serum proteins of the control rabbits represents damaged glucagon- $\mathrm{I}^{131}(14)$. These results indicate that significant levels of glucagon-binding globulins occur only after repeated injections of glucagon, thereby indicating its antigenicity.

The quantitative authenticity of the above results was verified by a different method, the SkomTalmage technique (15), in which the radioantigen-antibody complex is separated from free radioantigen by precipitation of the former with specific antiglobulin serum. In the serum of Rabbit G-23, for example, in which 85 per cent of the glucagon- $\mathrm{I}^{131}$ was found by the BersonYalow technique to be bound to globulin, 87 per cent of the glucagon-I ${ }^{131}$ was found by the SkomTalmage technique to be bound to globulin.

Cross reaction between insulin and glucagon. In order to exclude cross reactivity between insulin and glucagon, glucagon- $\mathrm{I}^{131}$ was incubated with

TABLE I

Tests of cross reactivity between glucagon- $I^{131}$ and insulin- $I^{131}$ and their antibodies

\begin{tabular}{clc}
\hline \hline Radioantigen & \multicolumn{1}{c}{ Serum } & $\begin{array}{c}\text { \% Bound to } \\
\text { globulin }\end{array}$ \\
\hline \multirow{3}{*}{ Glucagon-I $^{131}$} & Antiglucagon & 73.1 \\
& Anti-insulin & 19.8 \\
& Non-immune & 17.7 \\
& Antiglucagon & 19.7 \\
Insulin-I ${ }^{131}$ & Anti-insulin & 90.3 \\
& Non-immune & 20.7 \\
\hline
\end{tabular}

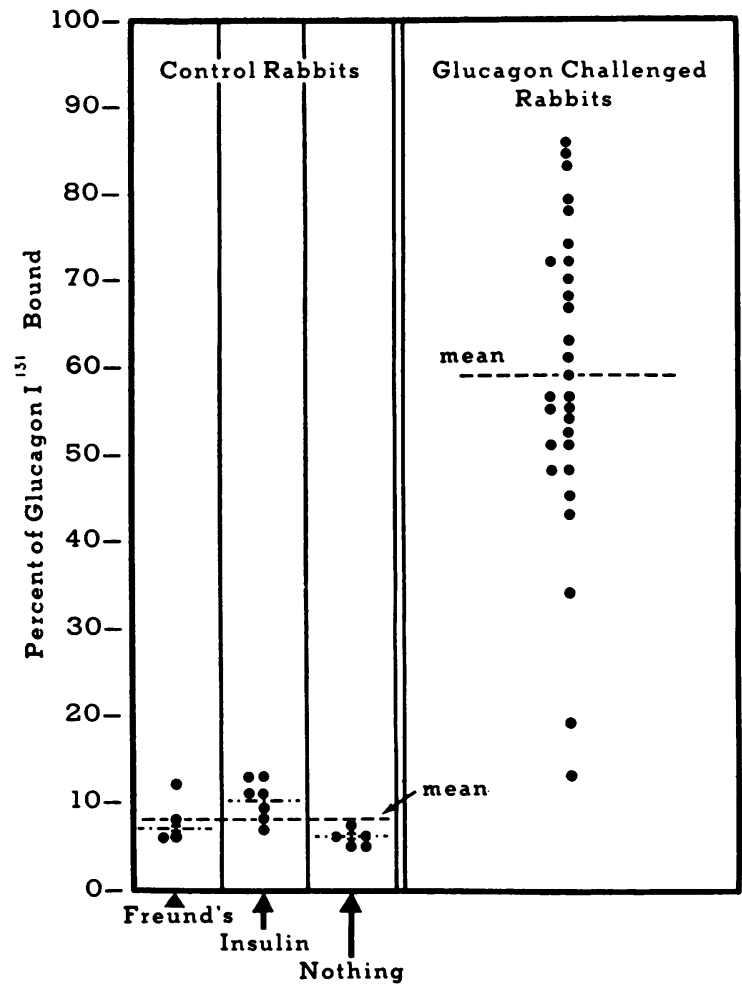

Fig. 2. Binding OF GLUCAGon-I ${ }^{131}$ IN RABBIt SERUM. The percentage of $10 \mathrm{~m} \mu \mathrm{g}$ of glucagon $-\mathrm{I}^{131}$ which migrated chromatographically with globulin in the serum of 29 rabbits challenged with monthly injections of beef-pork glucagon in Freund's adjuvant, is indicated on the right (range of migration 13.4 to 84.6 per cent ; mean 58.5). The per cent migration in the serum of 18 control rabbits is recorded on the left. In 6 uninjected controls, migration was 4.8 to 7.2 per cent (mean 5.8 ); in 7 rabbits receiving "glucagon-free" insulin in Freund's adjuvant, migration was 7.3 to 13.4 per cent (mean 10.4); in rabbits injected with Freund's adjuvant alone migration ranged from 5.9 to 12.0 per cent (mean 7.7). The results indicate the antigenicity of beef-pork glucagon in rabbits.

anti-insulin rabbit serum and insulin- $\mathrm{I}^{131}$ with antiglucagon serum, and binding of the radioantigens to globulin measured chromatographically. As indicated in Table I, no evidence of cross reactivity was noted, the binding of insulin$\mathrm{I}^{131}$ to globulins in antiglucagon serum and of glucagon- $\mathrm{I}^{131}$ in anti-insulin serum being no greater than in non-immune sera.

Protection of glucagon from proteolytic degradation. It has been shown that the binding of insulin to insulin antibody protects the former from degradation by insulinase (18). In order to 


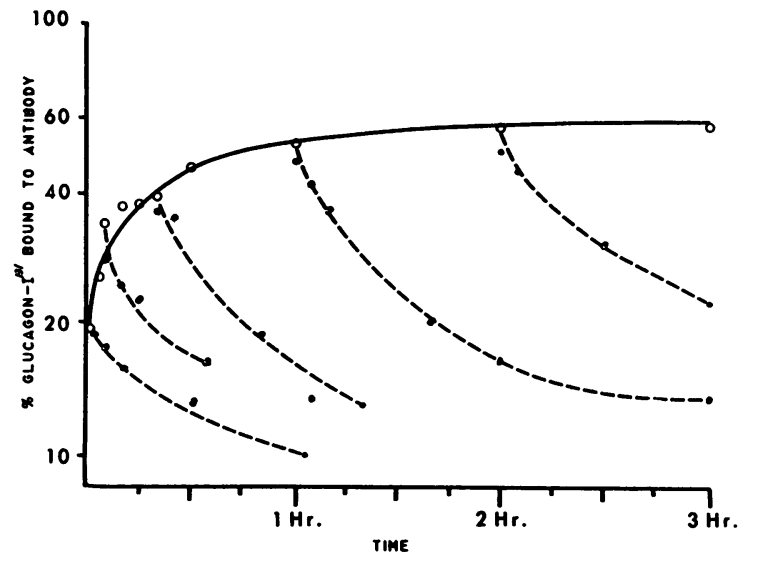

Fig. 3. Rate of association and dissociation of GLUCAGON-I $\mathrm{I}^{131}$ AND ITS ANTIBODY. Glucagon- $\mathrm{I}^{131}$ (12.3 $\mathrm{m} \mu \mathrm{g}$ ) was incubated with a $1: 10$ dilution of pooled rabbit antiglucagon serum and aliquots were removed at various times up to 3 hours thereafter and the per cent migration at these times determined. The open circles indicate the rate of formation of the radioantigen-antibody complex. Subaliquots of the incubating mixture of glucagon- $\mathrm{I}^{131}$ and antiserum were removed at 5 different points and swamping quantities of nonradioactive glucagon added in order to study dissociation of the radioantigen-antibody complex. The solid circles show the per cent bound to antibody at various times after the addition of the "cold" glucagon and indicate the rate of dissociation of the radioantigen-antibody complex as antibody-bound glucagon- $\mathrm{I}^{131}$ is exchanged for and diluted out by the nonradioactive glucagon. The results indicate the rate of dissociation of the complex and demonstrate the reversibility of the antigen-antibody reaction.

determine whether glucagon antibodies similarly protect glucagon from degradation by plasmin, shown by Mirsky, Perisutti and Davis to degrade glucagon (19), $1 \mathrm{~m} \mu \mathrm{g}$ of glucagon- $\mathrm{I}^{131}$ was incubated in the described manner with both antiglucagon serum and a non-immune serum. After the usual overnight incubation $1,000 \mathrm{U}$ of buffered streptokinase (Varidase) in fresh human plasma was added and incubated with the mixture for 90 minutes at $37^{\circ} \mathrm{C}$ by the Mirsky method (19). In the presence of antiglucagon serum, only 8.2 per cent of the glucagon- $\mathrm{I}^{131}$ was degraded, as indicated by loss of trichloroacetic acid-precipitable radioactivity, as compared with 37.3 per cent degradation in the control sample containing non-immune rabbit serum.

Kinetic studies. The methods used by Berson and Yalow (20), to characterize the reaction between insulin and its antibody were employed in these studies to examine the patterns of formation and dissociation of the glucagon-antibody complex. Glucagon- $\mathrm{I}^{131}(12.3 \mathrm{~m} \mu \mathrm{g})$ was incubated in a $1: 10$ dilution of pooled rabbit antiglucagon serum at $37^{\circ} \mathrm{C}$, and aliquots were removed at varying intervals to determine by paper chromatography the amount of glucagon- $\mathrm{I}^{131}$ bound to antibody after various time intervals. The results of such an experiment are recorded in Figure 3 , and the rate of association at that temperature is indicated.

To study dissociation of the glucagon- $\mathrm{I}^{131}$ antibody complex, saturating quantities $(10 \mu \mathrm{g})$ of nonradioactive glucagon were added at varying times to aliquots of the incubating mixture. Samples of these were removed at varying intervals and the changes in the percentage of glucagon- $\mathrm{I}^{131}$ bound to antibody were determined. Reversibility of the reaction would be indicated by a decrease in antibody-bound radioactivity as glucagon- $\mathrm{I}^{131}$ equilibrates with, and is exchanged for, the more plentiful nonradioactive glucagon. Evidence of reversibility and an example of the rate at which dissociation takes place are given in Figure 3.

It has been shown that the insulin-binding reaction obeys the law of mass action (8). At a constant antibody concentration, the amount of insulin-binding increases with the quantity of insulin incubated, although the fraction of the incubated insulin that is bound declines. The results of the experiment shown in Figure 4 indicate that glucagon-binding is similar in this respect.

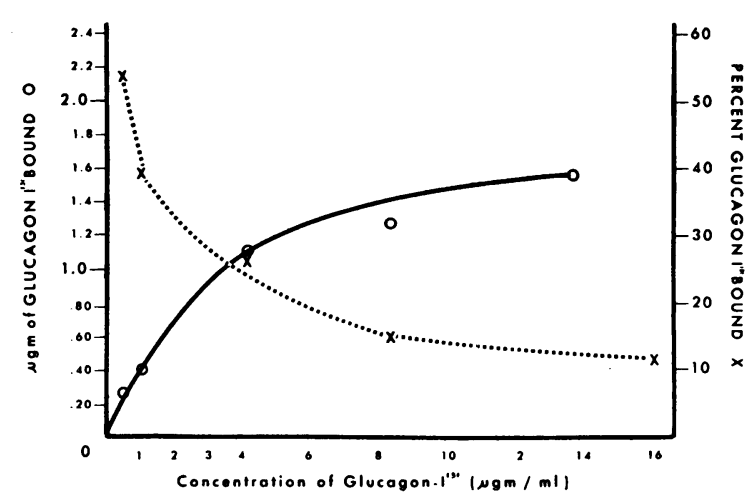

Fig. 4. THE efFect of varying the concentration OF GLUCAGON-I ${ }^{131}$ UPON THE AMOUNT (LEFT) AND PER CENT (RIGHT) OF GLUCAGON-I ${ }^{131}$ BINDING TO ANTIBODY IN UNDILUTED RABBIT ANTIGLUCAGON SERUM. The amount bound $(O)$ increases nonlinearly, suggesting a "mass action" effect, while the percentage bound $(X)$ declines progressively. 

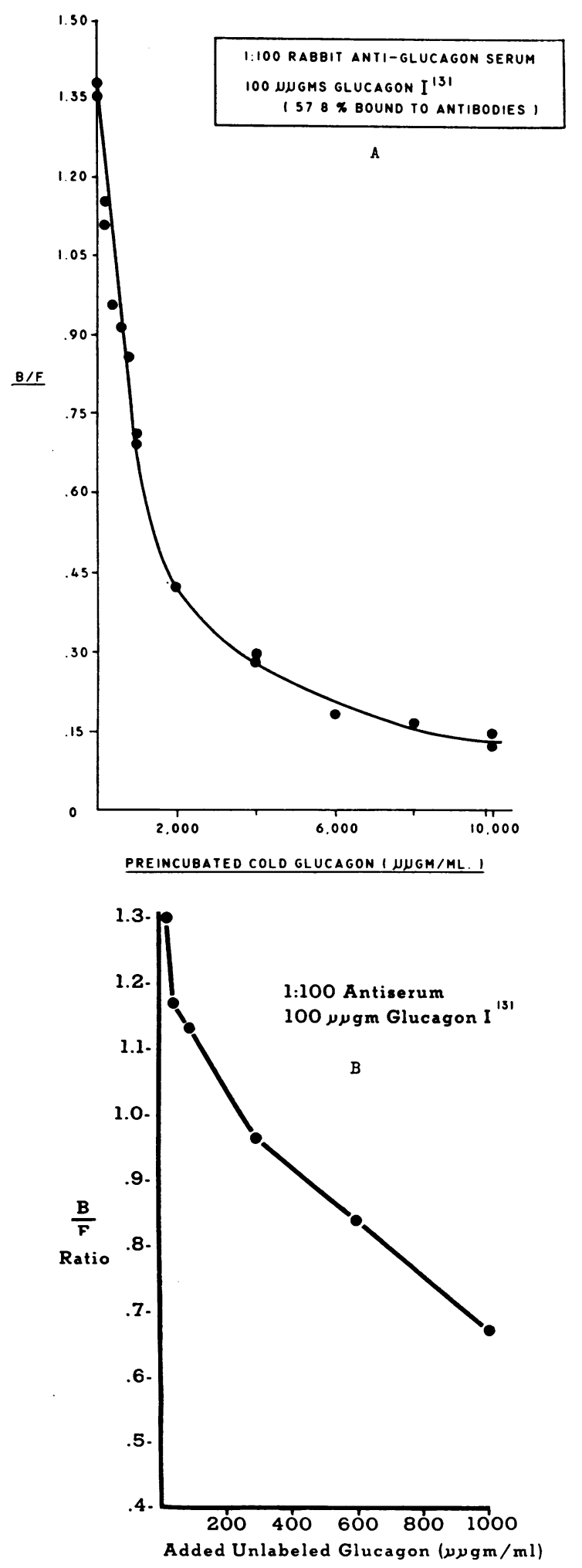

Fig. 5. Standard glucagon assay curve. A. Preincubation in a 1:100 dilution of serum of increasing

\section{Immunoassay}

Standard curves. When unlabeled glucagon in 5 per cent albumin solution is incubated with antiglucagon serum prior to incubation of the antiserum with glucagon- $\mathrm{I}^{131}$, the $\mathrm{B} / \mathrm{F}$ ratio of the latter will fall. The magnitude of this fall is related to the quantity of the unlabeled glucagon that has been added. When the $\mathrm{B} / \mathrm{F}$ ratio is plotted as a function of the quantity of added unlabeled glucagon, a characteristic curve is obtained which serves as the standard curve for the assay (Figure 5A, B). In general, an unequivocal decline in $\mathrm{B} / \mathrm{F}$ ratio from the values obtained with a 5 per cent albumin blank is encountered whenever the quantity of unlabeled glucagon approaches or exceeds the amount of glucagon- $\mathrm{I}^{131}$ in the system. Initially, relatively small amounts of unlabeled glucagon cause a proportionately large fall in $\mathrm{B} / \mathrm{F}$ ratio, but with larger amounts a progressively smaller decline is noted and the curve approaches the horizontal.

The ability of other pepticle hormones, glucagon-free insulin, vasopressin, and $\mathrm{ACTH}$, to lower the $\mathrm{B} / \mathrm{F}$ ratio of glucagon- $\mathrm{I}^{131}$ was tested and compared with that of glucagon (Table II). Only glucagon caused a significant decline in the $\mathrm{B} / \mathrm{F}$ ratio of glucagon- $\mathrm{I}^{131}$, suggesting a high degree of specificity for the assay method.

Because it was not possible by means of current techniques and equipment to count less than 50 to $100 \mu \mu \mathrm{g}$ of glucagon- $\mathrm{I}^{131}$, maximal sensitivity possible under these circumstances was 50 to 100 $\mu \mu \mathrm{g}$ of glucagon. In achieving this level of sensitivity, a $1: 100$ dilution of the pooled antiserum was employed (Figure 5B).

Although curves made with different lots of glucagon-I ${ }^{131}$ and different lots of dilute anti-

amounts of nonradioactive glucagon, from 2,000 to 10 ,$000 \mu \mu \mathrm{g}$ causes a progressive decline in the $\mathrm{B} / \mathrm{F}$ ratio of $100 \mu \mu \mathrm{g}$ of glucagon- $\mathrm{I}^{131}$. A plot of $\mathrm{B} / \mathrm{F}$ as a function of the amount of preincubated "cold" glucagon yields the above characteristic curve which serves as a standard curve in the glucagon assay. The high degree of reproducibility is indicated by the proximity of the duplicate determinations.

B. Maximal sensitivity attainable by currently employed techniques is $50 \mu \mu \mathrm{g}$. In the above curve, 50 $\mu \mu \mathrm{g}$ of "cold" glucagon caused a significant fall in the $\mathrm{B} / \mathrm{F}$ ratio of glucagon- $\mathrm{I}^{131}$. 
TABLE II

Effect of various polypeptide hormones on $B / F$ ratio $^{*}$ of glucagon- $I^{131}$

\begin{tabular}{|c|c|c|c|c|c|c|}
\hline \multirow{2}{*}{$\begin{array}{l}\text { Hormone } \\
\text { concen- } \\
\text { tration }\end{array}$} & \multicolumn{2}{|c|}{$\begin{array}{c}\text { Glucagon-free } \\
\text { insulin }\end{array}$} & \multirow{2}{*}{$\begin{array}{l}\text { Vaso- } \\
\text { pressin }\end{array}$} & \multirow[b]{2}{*}{ ACTH } & \multicolumn{2}{|c|}{ Glucagon } \\
\hline & Exp. I & Exp. II & & & Exp. I & Exp. II \\
\hline \multicolumn{7}{|l|}{$\mu \mu g / m l$} \\
\hline \multirow{3}{*}{$\begin{array}{r}0 \\
100 \\
200 \\
400 \\
600 \\
800\end{array}$} & \multirow{2}{*}{$\begin{array}{l}1.030 \\
1.379 \\
1.424 \\
1.039\end{array}$} & \multirow[t]{2}{*}{1.173} & \multirow[t]{2}{*}{1.173} & \multirow[t]{3}{*}{1.379} & $\begin{array}{l}1.030 \\
0.930 \\
0.796\end{array}$ & 1.173 \\
\hline & & & & & & 1.020 \\
\hline & \multirow{6}{*}{$\begin{array}{l}1.039 \\
1.110\end{array}$} & & & & & \\
\hline $\begin{array}{l}1,000 \\
4,000\end{array}$ & & 0.990 & 1.063 & & 0.258 & 0.774 \\
\hline 5,000 & & 0.979 & 1.002 & & & 0.282 \\
\hline $\begin{array}{r}0,000 \\
10,000\end{array}$ & & 0.956 & 0.988 & 1.143 & $\begin{array}{l}0.202 \\
0.129\end{array}$ & 0.152 \\
\hline 15,000 & & 0.981 & 0.943 & & & 0.114 \\
\hline 20,000 & & 0.983 & 1.154 & & & 0.075 \\
\hline
\end{tabular}

* Ratio of antibody-bound to free glucagon-I ${ }^{131}$.

serum differed from each other to a varying degree, excellent reproducibility was noted when the same standards and other materials were set up in duplicate on the same day (Figure 5A). Under these circumstances, the standard deviation from the mean of 35 consecutive duplicate $\mathrm{B} / \mathrm{F}$ ratios of glucagon standard solutions was \pm 0.0436 .

In vivo recovery of exogenous glucagon. The disappearance rate of beef-pork glucagon- $\mathrm{I}^{131}$ following its intravenous injection in man has been studied previously by measurements of the level of trichloroacetic acid-precipitable radioactivity in plasma. Measurements in this laboratory in normal humans reveal a rapid logarithmic decline in glucagon- $\mathrm{I}^{131}$ plasma concentration with a halflife of approximately 10 minutes. In order to test the ability of the immunoassay to measure exogenous beef-pork glucagon in vivo, $3 \mathrm{mg}$ of unlabeled glucagon was injected intravenously, and blood specimens were drawn at intervals for 1 hour thereafter. Measurements of glucagon concentration by means of the immunoassay gave a disappearance curve for exogenous glucagon quite similar in form to that obtained by radioactivity measurements after radioglucagon administration (Figure 6). The higher plateau of trichloroacetic acid-precipitable radioactivity is attributed to the altered glucagon- $\mathrm{I}^{131}$ which binds to serum proteins and disappears less rapidly than undamaged glucagon- $\mathrm{I}^{131}$.

Endogenous glucagon. Since an immunoassay for glucagon would be employed primarily for the study of endogenous glucagon levels in dogs and in humans, it seemed important to determine whether cross reactivity between rabbit antibodies to beef-pork glucagon and canine or human glucagon exists. The pancreases of an anesthetized dog and of three deceased humans were obtained and immediately frozen. These organs were extracted by the method of Sutherland and de Duve (17) and the dried residue reconstituted in chloride-phosphate buffer containing 2 per cent albu-

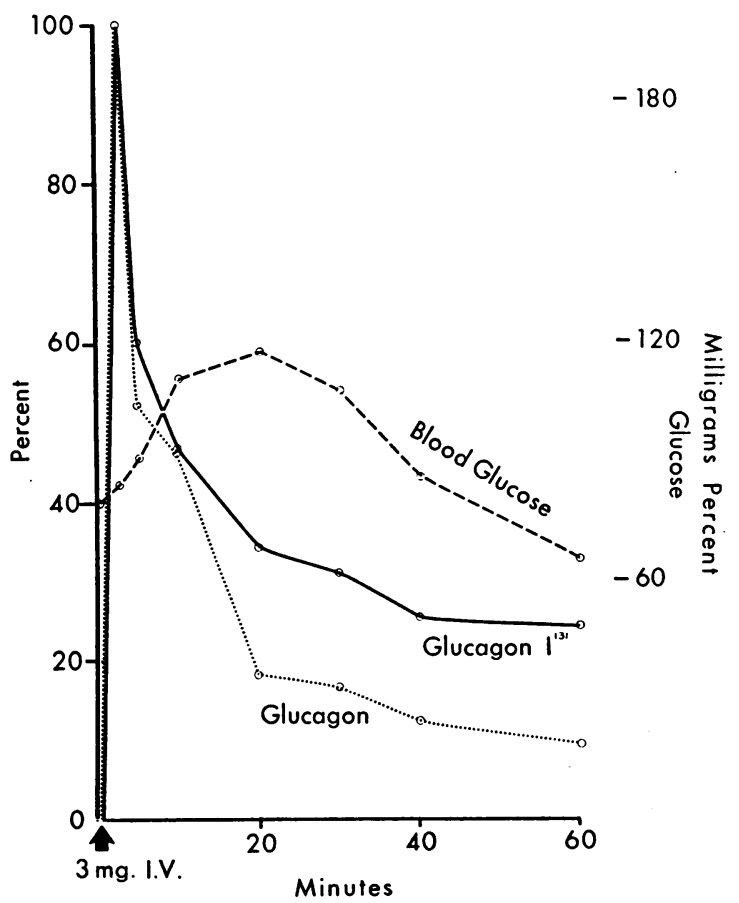

Fig. 6. Glucagon time-disappearance curve. The plasma disappearance rate of $3 \mathrm{mg}$ of glucagon- $\mathrm{I}^{131}$ was determined after its intravenous injection into a normal subject (solid line) by measuring the trichloroacetic acid-precipitable radioactivity in plasma at multiple intervals for 1 hour after injection. In a second normal subject $3 \mathrm{mg}$ of nonradioactive glucagon was injected and its rate of disappearance measured by means of the radio-immunoassay (dotted line). Although the absolute concentration of glucagon in $\mathrm{m} \mu \mathrm{g} / \mathrm{ml}$ differed widely in each subject at any given time, the form of the two disappearance curves was quite similar when, as was done above, glucagon concentration was calculated as per cent of the peak 2.5 minute concentration. The higher values for glucagon- $\mathrm{I}^{131}$ obtained after 10 minutes are the result of persistent circulation of damaged glucagon- $\mathrm{I}^{131}$ which does not disappear at a rate comparable with the undamaged material, remaining bound to serum proteins. The blood glucose concentration of the patient who received nonradioactive glucagon is charted above; the other patient, whose blood glucose response curve is not charted, had a more striking hyperglycemic response. 
TABLE III

Measurements of endogenous glucagon in pancreatic extracts

\begin{tabular}{|c|c|c|c|c|c|c|c|}
\hline \multirow[b]{3}{*}{ Dilution of extract } & \multirow[b]{3}{*}{ Dog pancreas } & \multicolumn{5}{|c|}{$\mathrm{B} / \mathrm{F}$ ratios and glucagon concentrations in $\mu \mu$ equivalents per $\mathrm{ml}$} & \multirow{3}{*}{$\begin{array}{l}\underset{\text { Human }}{\text { liver }} \\
\text { R.M.* }\end{array}$} \\
\hline & & \multirow{2}{*}{$\begin{array}{l}\text { Human } \\
\text { pancreas } \\
\text { M.H.** }\end{array}$} & \multirow{2}{*}{$\begin{array}{l}\underset{\text { Human }}{\text { pancreas }} \\
\text { R.M.** }\end{array}$} & \multicolumn{2}{|c|}{ Human pancreas W.M. $\dagger$} & \multirow{2}{*}{$\begin{array}{l}\text { Human } \\
\text { kidney } \\
\text { R.M.* }\end{array}$} & \\
\hline & & & & Head & Tail & & \\
\hline $1: 10$ & $\begin{array}{c}0.005 \mathrm{~B} / \mathrm{F} \\
>10,000 \mu \mu \mathrm{g} / \mathrm{ml}\end{array}$ & & $\begin{array}{c}0.007 \mathrm{~B} / \mathrm{F} \\
10,000 \mu \mu \mathrm{g} / \mathrm{ml}\end{array}$ & $\begin{array}{c}0.066 \mathrm{~B} / \mathrm{F} \\
>10,000 \mu \mu \mathrm{g} / \mathrm{ml}\end{array}$ & $\begin{array}{c}0.008 \mathrm{~B} / \mathrm{F} \\
>10,000 \mu \mu \mathrm{g} / \mathrm{ml}\end{array}$ & $\begin{array}{l}1.01 \mathrm{~B} / \mathrm{F} \\
0 \mu \mu \mathrm{g} / \mathrm{ml}\end{array}$ & $\begin{array}{r}1.271 \mathrm{~B} / \mathrm{F} \\
0 \mu \mu \mathrm{g} / \mathrm{ml}\end{array}$ \\
\hline $1: 20$ & & 0.310 & & & & & \\
\hline $1: 100$ & $\begin{array}{l}0.061 \mathrm{~B} / \mathrm{F} \\
6,800 \mu \mu \mathrm{g} / \mathrm{ml}\end{array}$ & & $\begin{array}{l}0.059 \mathrm{~B} / \mathrm{F} \\
3,150 \mu \mu \mathrm{g} / \mathrm{ml}\end{array}$ & $\begin{array}{l}0.864 \mathrm{~B} / \mathrm{F} \\
620 \mu \mu \mathrm{g} / \mathrm{ml}\end{array}$ & $\begin{array}{l}0.314 \mathrm{~B} / \mathrm{F} \\
1,880 \mu \mu \mathrm{g} / \mathrm{ml}\end{array}$ & & \\
\hline $1: 400$ & & & $\begin{array}{l}0.391 \mathrm{~B} / \mathrm{F} \\
1,650 \mu \mu \mathrm{g} / \mathrm{ml}\end{array}$ & $\begin{array}{l}1.149 \mathrm{~B} / \mathrm{F} \\
0 \mu \mu \mathrm{g} / \mathrm{ml}\end{array}$ & $\begin{array}{l}0.817 \mathrm{~B} / \mathrm{F} \\
710 \mu \mu \mathrm{g} / \mathrm{ml}\end{array}$ & & \\
\hline $1: 800$ & & & $\begin{array}{l}0.890 \mathrm{~B} / \mathrm{F} \\
590 \mu \mu \mathrm{g} / \mathrm{ml}\end{array}$ & $\begin{array}{l}1.244 \mathrm{~B} / \mathrm{F} \\
0 \mu \mu \mathrm{g} / \mathrm{ml}\end{array}$ & $\begin{array}{l}1.209 \mathrm{~B} / \mathrm{F} \\
0 \mu \mu \mathrm{g} / \mathrm{ml}\end{array}$ & & \\
\hline $\begin{array}{l}\text { Total glucagon content } \\
\text { of organ }(\mu \mathrm{Eq})\end{array}$ & $22.4 \mu \mathrm{g}$ & & $26-36.3 \mu \mathrm{g}$ & $3.7 \mu \mathrm{g}$ & $8.8-13.4 \mu \mathrm{g}$ & $0 \mu \mathrm{g}$ & $0 \mu \mathrm{g}$ \\
\hline
\end{tabular}

* Obtained 2 hours post mortem.

$\dagger$ Obtained 5 hours post mortem.

min to $1 \mathrm{ml}$ per $\mathrm{g}$ of original wet weight. Ten to 800 -fold dilutions were then made with the same albumin-buffer solution, and 1-ml samples of these dilutions were assayed for glucagon. Table III reveals the profound depression of $\mathrm{B} / \mathrm{F}$ ratio caused by extracts of both human and canine pancreas as compared with control organs. The estimated glucagon concentrations are expressed in micromicroequivalents of beef-pork glucagon per milliliter. Calculations of the total glucagon content of pancreas of both species range from 12.5 to $36.3 \mu \mathrm{Eq}$ of beef-pork glucagon.

The results clearly demonstrate the existence of canine and human glucagon and indicate that some cross reactivity with rabbit antibodies to beef-pork glucagon is present.

\section{DISCUSSION}

The data confirm the previously reported (9) antigenicity of beef-pork glucagon in rabbits. Furthermore, they indicate that in virtually every category examined glucagon-binding antibodies appear to resemble insulin-binding antibodies.

Like insulin antibodies, glucagon antibodies are of the nonprecipitating type and can, therefore, be detected only by such methods as the paper chromato-electrophoretic technique of Berson and coworkers (8), or the Skom-Talmage technique (15), each of which permits separation of free glucagon- $\mathrm{I}^{131}$ from antibody-bound glucagon- $\mathrm{I}^{131}$. Whereas the insulin-binding antibody of humans and guinea pigs is in the inter- $\gamma, \beta$-zone, the glucagon-binding antibody of rabbits appears to migrate electrophoretically as a $\gamma$-globulin. Kinetic similarities between insulin-binding and glucagonbinding reactions were observed. First, the reaction of glucagon and its antibody was found to be reversible. Second, like insulin-binding, glucagonbinding was governed by the law of mass action; at a constant antibody concentration, the amount of glucagon- $\mathrm{I}^{131}$ bound increased as the concentration of glucagon- $\mathrm{I}^{131}$, although the percentage of glucagon- $\mathrm{I}^{131}$ bound decreased progressively.

The only previous suggestion of glucagon antigenicity consists of a report by Carleton, Greben and Schulman (21) of a hypotensive reaction following an intravenous injection of glucagon in a patient who had previously had insulin shock therapy. Since commercial insulin is contaminated with glucagon, it is possible that this was an instance of glucagon sensitivity in humans. Except for this unproven case, the present studies constitute the only evidence for glucagon antigenicity in any species. Preliminary studies in our laboratory indicate the presence of small amounts of nonprecipitating antibodies to glucagon in some insulin-treated diabetic patients (22). Although the clinical significance of this 
evidence of glucagon antigenicity in man is doubtful, it may be well to keep this possibility in mind in puzzling cases of allergy ascribed to insulin.

The competitive inhibition by nonradioactive glucagon upon the reaction between glucagon- $\mathrm{I}^{131}$ and its antibody, fully predictable from the foregoing kinetic studies, provides the basis of the immunoassay. If, in a system containing traces of glucagon- $\mathrm{I}^{131}$ and dilute antiserum, increasing amounts of nonradioactive glucagon are added, the $\mathrm{B} / \mathrm{F}$ ratio of radioglucagon will progressively decline. A plot of the $\mathrm{B} / \mathrm{F}$ ratio as a function of the amount of nonradioactive glucagon added gives a characteristic curve which serves as the standard curve of the assay.

In contrast to bioassay methods which measure only "glucagon-like" activity, the radio-immunoassay appears to be highly specific and exquisitely sensitive. The assumption of specificity is based upon the demonstrated lack of cross reactivity between glucagon antibodies and polypeptide hormones other than glucagon, i.e., insulin, vasopressin, and ACTH. The maximal sensitivity of the technique, at present $50 \mu \mu \mathrm{g}$ per $\mathrm{ml}$, is greater than the maximal sensitivity of the earlier bioassay methods. Furthermore, additional increase in sensitivity is presumably possible.

The marked competitive action in the assay system exerted by pancreatic extracts from both dog and man not only provides specific evidence of the presence of glucagon in both these species but gives assurance of at least some cross reactivity between rabbit antibodies to beef-pork glucagon and both human and canine glucagon. Although the low values for total pancreatic glucagon content may suggest that cross reactivity is rather limited, they may reflect postmortem glucagon destruction or inefficiency of the extraction technique. In any case, since some cross reactivity is a prerequisite to the measurement of endogenous glucagon in these species, it seems possible that the immunoassay for glucagon will permit the exploration of the hormonal status of endogenous glucagon in health and disease.

\section{SUMMARY}

Monthly injections in rablits of beef-pork glucagon in Freund's adjuvant resulted in the appearance of nonprecipitating glucagon-binding antibodies detectable both by the method of Berson and Yalow and that of Skom and Talmage. As in the case of insulin antibodies, the reaction between glucagon- $\mathrm{I}^{131}$ and glucagon antibodies was a reversible one, governed by the law of mass action.

The preincubation of nonradioactive glucagon with antiglucagon serum reduced binding of glucagon- $\mathrm{I}^{131}$ to a degree related to the quantity preincubated, thereby providing the basis of a radioimmunoassay for glucagon. Other peptide hormones, including insulin, did not influence glucagon-I ${ }^{131}$-binding, implying a high degree of specificity for the assay, which was found capable of measuring as little as $50 \mu \mu \mathrm{g}$ per $\mathrm{ml}$ of glucagon.

The assay was used to measure the disappearance of glucagon following its intravenous injection in a normal man. The resulting curve resembled in form the plasma disappearance curve of glucagon-I ${ }^{131}$.

High glucagon concentrations, measurable in extracts of human and canine pancreas, indicate cross reaction between the glucagon of these species and antibodies to beef-pork glucagon, which should make possible the first specific explorations of circulating endogenous glucagon in health and disease.

\section{ACKNOWLEDGMENTS}

The authors wish to thank Drs. Solomon A. Berson and Rosalyn S. Yalow for valued advice. They are indebted to Mrs. Genevieve Thompson for technical contributions, to Mrs. Patsy Rupard and Miss Pam Young for stenographic help, to the late Mr. John Ash for designing the chromatography boxes, and to Mr. Walter F. Sullivan and Clyde Tilton for the illustrations.

\section{REFERENCES}

1. Staub, A., Sinn, L., and Behrens, O. K. Purification and crystallization of glucagon. J. biol. Chem. 1955, 214, 619.

2. Bornstein, J., Reid, E., and Young, F. G. The hyperglycaemic action of blood from animals treated with growth hormone. Nature (Lond.) 1951, 168, 903.

3. Staub, A., Springs, V., and Elrick, H. Effect of glucagon on renal excretion of electrolytes. Fed. Proc. 1956, 15, 361.

4. Tyberghein, J. M., and Williams, R. H. Assay for glucagon in rabbit plasma. Metabolism 1958, 7, 635.

5. Makman, M. H., Makman, R. S., and Sutherland, E. W. Presence of a glucagon-like material in 
blood of man and dog. J. biol. Chem. 1958, 233, 894.

6. Berthet, J. Some aspects of the glucagon problem. Amer. J. Med. 1959, 26, 703.

7. Arquilla, E. R., and Stavitsky, A. B. Evidence for the insulin-directed specificity of rabbit anti-insulin serum. J. clin. Invest. 1956, 35, 467.

8. Berson, S. A., Yalow, R. S., Bauman, A., Rothschild, M. A., and Newerly, K. Insulin- $\mathrm{I}^{131}$ metabolism in human subjects. Demonstration of insulin binding globulin in the circulation of insulin treated subjects. J. clin. Invest. 1956, 35, 170.

9. Unger, R. H., Eisentraut, A. M., McCall, M. S., Keller, S., Lanz, H. C., and Madison, L. L. Glucagon antibodies and their use for immunoassay for glucagon. Proc. Soc. exp. Biol. (N. Y.) 1959 $102,621$.

10. Berson, S. A. and Yalow, R. S. Isotopic tracers in the study of diabetes. Advanc. biol med. Phys. 1958, 6, 349.

11. Yalow, R. S., and Berson, S. A. Immunoassay of endogenous plasma insulin in man. J. clin. Invest. 1960, 39, 1157.

12. Pressman, D., and Eisen, H. N. Zone of localization of antibodies; attempt to saturate antibodybinding sites in mouse kidney. J. Immunol. 1950, 64, 273.

13. McCall, M. S., Timm, L., Eisentraut, A. M., and Unger, R. H. The preparation of high specific activity glucagon- $\mathrm{I}^{131}$. To be published.
14. Berson, S. A., Yalow, R. S., and Volk, B. W. In vivo and in vitro metabolism of insulin- $\mathrm{I}^{131}$ and glucagon- $\mathrm{I}^{131}$ in normal and cortisone-treated rabbits. J. Lab. clin. Med. 1957, 49, 331.

15. Skom, J. H., and Talmage, D. W. Nonprecipitating insulin antibodies. J. clin. Invest. 1958, 37, 783.

16. Grodsky, G. M., and Forsham, P. H. An immunochemical assay of total extractable insulin in man. J. clin. Invest. 1960, 39, 1070.

17. Sutherland, E. W., and de Duve, C. Origin and distribution of the hyperglycemic-glycogenolytic factor of the pancreas. J. biol. Chem. 1948, 175, 663.

18. Yalow, R. S., and Berson, S. A. Apparent inhibition of liver insulinase activity by serum and serum fractions containing insulin-binding antibody. $\mathrm{J}$. clin. Invest. 1957, 36, 648.

19. Mirsky, I. A., Perisutti, G., and Davis, N. C. The destruction of glucagon, adrenocorticotropin and somatotropin by human blood plasma. J. clin. Invest. 1959, 38, 14.

20. Berson, S. A., and Yalow, R. S. Quantitative aspects of the reaction between insulin and insulinbinding antibody. J. clin. Invest. 1959, 38, 1996.

21. Carleton, J. L., Greben, S. E., and Schulman, J. L. Hypotensive reaction following the use of glucagon. A. M. A. Arch. intern. Med. 1957, 99, 817.

22. Unger, R. H., Sims, K., and Eisentraut, A. M. Unpublished observations. 